\title{
類似施設との比較によるお笑い劇場利用者行動の特徵 拈笑い劇場の利用者行動と顧客満足に関する研究 その 1 \\ THE FEATURE OF THE USER'S BEHAVIOR IN COMEDY THEATER BY COMPARISON WITH ANOTHER KIND OF THEATER
}

A study on comedy theater user's behavior and customer satisfaction Part 1

山本杏子*, 小島隆矢**

Kyoko YAMAMOTO and Takaya KOJIMA

This study examines the feature of the user's behavior in a comedy theater by comparison with another kind of theater. First survey researched the user type and user's needs. Second survey researched for user's behavior before and after performance to analyze behavior of the environment around theater affects revisit of a theater. The results are as followings:

1) Comedy theaters are places which young women visit with their friend, and are used for their communication.

2) The ease of behavior of the environment around a comedy theater affects the revisit intention of a theater.

Keywords :comedy theater, user's behavior, surrounding area environment, revisit intention, theaters and halls, Structural Equation Modeling お笑い劇場，利用者行動，周辺環境，再訪意向，劇場・ホール，構造方程式モデリング

\section{1. はじめに}

現代日本の大衆文化においては 1980 年より始まった「MANZAI ブ

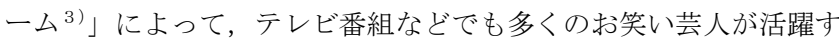
るようになり，我々の日常生活にはお笑い文化が溶け込んでいる。 そんな中，大御所から若手芸人まで様々な芸を生で見ることができ る「お笑い劇場（漫才，コント，新喜劇，落語などのお笑い専用に つくられた劇場)」が次々と開館し，お笑い文化を支える重要な基盤 の 1 つとして存在感を増している。

そこで本研究では，より多くの人が訪れたいと思えるお笑い劇場 のあり方について知見を得ることを目的として，様々な検討を行う。 まず本報では，お笑い劇場の利用者像を明確化するため，利用様 態・利用者行動を類似施設と比較しつつ把握することを試みる。

\section{2. 研究の背景}

本章では，本研究の背景としてお笑い劇場を取り巻く社会的現状 を踏まえ, 現代社会におけるお笑い劇場の役割や抱える問題および 既往研究について述べる。

\section{1 お笑い劇場の社会的現状}

近年，日本のアイドルやアニメ，ファッションなど，いわゆる少 ブカルチャーが諸外国から注目されている。その中心的な役割を果 たしているのが，10 代 20 代の若年の女性である。昨今，お笑い芸 人はこの世代の女性からアイドル視されており，「出待ち」や「追
つかけ」注2）をする女性も出現している。現代のお笑いブームは, このようなアイドル的人気による求心力の側面がある一方，老若男 女を問わず幅広く娛楽を提供している大衆文化という側面も持つ。 お笑い文化は，もはや日本を代表するサブカルチャーの 1 つといえ る。

そのような現在のお笑い文化の隆盛に対して，お笑い劇場がどの ような役割を担ってきたか，ここ十数年間の動向を概括しておく。 お笑い劇場は, 1994 年に吉本興業が従来の寄席や演芸場などの 古いイメージを脱して，より新しい雾囲気をかもし出すためにター ミナル駅周辺に劇場を構えることを計画し，まず銀座に銀座 7 丁目 劇場を開館した（岩田ほか4 ${ }^{4}$ より）。この劇場には当時の若手芸人 が多数出演し，アイドルの追っかけのような女性が集結することで 固定ファンがつき，テレビの最前線で活躍する芸人を生夕出した。 吉本興業は 1990 年以降，この銀座 7 丁目劇場に続き，渋谷公園通 り劇場，ルミネ the よしもと, 神保町花月, よしもとプリンスシア ターとお笑いブームが盛んになると共に東京都内でも次々と劇場を オープンさせた。

お笑い劇場の建築的な特徵としては，元々は多目的ホールであっ たところをお笑い専用劇場へと転用しているケースが多いため多目 的ホールと大きく逸脱している特徵はない。劇場の規模としては小 規模 (座席数約 $100 \sim 300$ 人) から中規模 (座席数約 300 人 800 人) までのものがあり，そのほとんどが小規模である。ステージと客席
* 早稲田大学大学院人間科学研究科 修士 (人間科学)

** 早稲田大学人間科学学術院 准教授 · 博士 (工学) 早稲田大学応用脳科学研究所
Grad. Stud., Grad. Sch. of Human Sciences, Waseda Univ.

Assoc. Prof., Faculty of Human Sciences, Waseda Univ., Dr. Eng. 
の位置関係はシューボックス型である。劇場ではほぼ毎日公演が行 なわれており，土日祝日は昼間から 1 日中公演が行なわれている。 興業形態としては，例えばルミネ the よしもとでは，第一部が 5〜 6 組の芸人によるネタ，第二部が吉本新喜劇の公演といった約 2 時間 の公演が一日に 3 回行われている。このような興業形態を基本とし ているが単独ライブやトークライブといった企画ものの公演が行わ れることもある。劇場ごとで公演内容や出演する芸人は異なるが興 業形態はほぼ同様である。

新宿や渋谷に建てられた劇場は, 若者の人気スポットとなり修学 旅行の新名所や観光地としても徐々に社会に浸透している。一方, 関西においても，大阪のなんばグランド花月は「笑いの総本山」と も呼ばれており, 多くの「観光客」が劇場に訪れている。また, 劇 場運営主体としても劇場周辺地域活性化につながる取り組み注3) が 行われている。これはお笑い劇場が単なる劇場ではなく, 周辺地域 の活性化や発展にも貢献している例である。

しかし，ブームとして劇場が次々と開館する一方で，閉館やリニ ユーアルを繰り返しているのもお笑い劇場の現状である。過去約 30 年間におけるお笑い劇場の開館と閉館を吉本興業が運営する劇 場を例に年表として図 1 に示す。お笑い劇場は 1986〜2010 年まで に 16 劇場が開館し, 既に 9 劇場が閉館している。また閉館した 9 劇 場のうち 6 劇場が 5 年以内に閉館している。これら劇場が閉館した 理由は賃貸契約期間満了のためとされているが，劇場周辺で遊ぶ場 所がない，近くに繁華街がないなど，お笑いファンにとって望まし

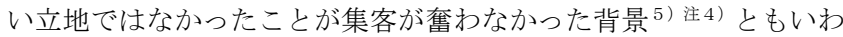
れている。また，お笑い劇場の所有・運営に関わる関係者数名への ヒアリング注5)を行ったところ，「立地や周辺環境も閉館の一因で あると考えているが，実際には何が原因で劇場が閉館するのか特定 できていない。だから閉館と開館を繰り返す場当たり的な劇場経営 となってしまう。」とのことであった。

\section{2 既往研究}

お笑い劇場の中でも伝統的な様式の寄席・演芸場に関する歴史研 究は別として，昨今のお笑いブームを背景として開館されたお笑い 専用劇場を対象とする建築学研究は今のところ皆無である。これは まだ世に出現してからの歴史が浅いことと, 語弊はあるが高尚 とはいえないイメージの大衆文化施設は学術研究の対象となり にくかったことが理由であると推察する。一方，コンサートホ 一ルや演劇を主体とする通常の用途の劇場を対象とした研究と しては，音響や座席からの視覚，劇場運営のためのマネジメン 卜，建築様式などをテーマとした様々な研究が行われている。 しかし，劇場を対象とした利用者行動や利用者ニーズに着目し た研究は少ない。建築学会における近年の発表論文としては, 以下の数件が挙げられる。

小野・小島ほか ${ }^{6)}$ は, 劇場・ホールを対象とした標準的な CS 調査票を作成することを目的に, ロック，クラシック，演劇， 伝統芸能の各公演内容の観客層を対象として劇場に対するニー ズ調査を行っている。その結果に基づき, ニーズ項目自体の共 通性は高い（従って, 公演内容によらず汎用の CS 調查票の作成 が可能である）が，どの項目を重視するかは公演内容によって 異なると報告している。

遠山ほか ${ }^{7)}$ は，鑑賞者は鑑賞後の余韻を保持し高めることの
できる環境を求めており, 劇場全体のデザインだけでなく鑑賞前後 の行動を考慮した鑑賞環境デザインの必要性を示している。

坂口ほか ${ }^{8)}$ は，劇場利用者の属性調査から公演内容や開演時間に よって劇場の利用者層が大きく異なることを示した。また，続報 （相田・坂口ほか9１0１））にて，鑑賞当日の劇場利用者の行動調査 に基づき，利用者は鑑賞前後の付加的行為によって劇場に行くこと に対する価值意識が育まれることを指摘した上で，劇場計画におい ては鑑賞者の鑑賞という行為のみを断片的に捉えるのではなく，日 常生活と連続した行為として位置づけ，環境等を含めて構築する必 要があると報告している。

以上の既往研究から，劇場の周辺環境は鑑賞者の期待や余韻に影 響し，その周辺環境をデザインするためには，利用者の利用様態の 特徴や鑑賞前後の行動を踏まえた劇場計画をする必要があると考え られる。また，演目内容によって劇場に対するニーズや鑑賞前後の 行動が異なることも予想され，これまでに研究例がない「お笑い劇 場」の利用者像把握のためにはあらためて調査を行う必要がある。

\section{3. 本研究の目的と構成 \\ 3. 1 研究の目的}

前章で論じた本研究の背景より次のことが言える。

・お笑い劇場は，人気と共に開館する一方で，閉館する劇場も多く 存在しており，閉館と開館を繰り返す場当たり的な劇場経営を行 なっている現状がある。

・閉館した劇場は, 劇場の立地や周辺環境がお笑いファンのニーズ を捉えていなかったことが一因といわれている。

・しかし実際には明確な閉館原因は把握されておらず，そのことが お笑い劇場が開館と閉館を繰り返す原因にもなっている。

・劇場の周辺環境を含めた鑑賞環境をデザインするためには，利用 者の鑑賞前後の行動を把握する必要がある。

本論文では，上記課題に応えるため，まず，お笑い劇場にはどの ような利用者が訪れているのか，利用者像の特徵を把握する。特に， お笑い劇場利用者の劇場周辺における利用者行動に着目し，実態把 握および集客への影響を把握する。これらを本研究の目的とする。

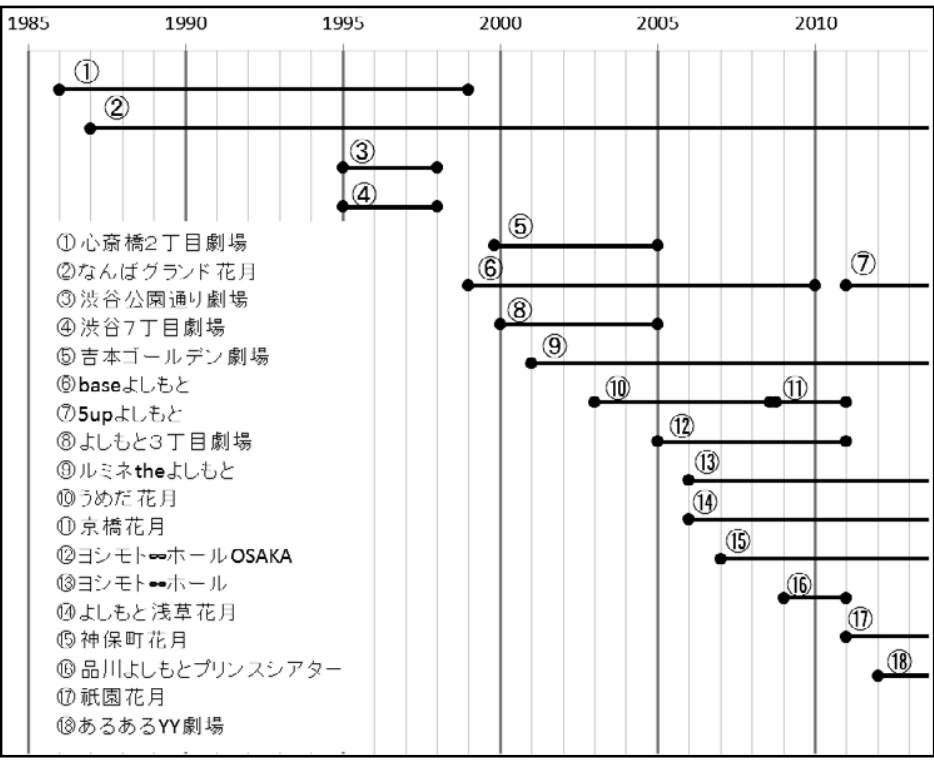

図 1 吉本興業における劇場の開館と閉館年表 
表 14 章の分析に用いる調查の概要注 6

\begin{tabular}{|c|c|c|c|c|c|c|c|}
\hline 調査名称·時期 & \multicolumn{4}{|c|}{ 劇場・ホール利用者調査 (2006.3) } & 映画館利用者調査 (2009.10) & \multicolumn{2}{|c|}{ お笑い劇場利用者調査 $(2010.10 \sim 11)$} \\
\hline 調査会社 & \multicolumn{4}{|c|}{ インタースコープ(株) } & ヤフー・バリュー・インサイト(株) & \multicolumn{2}{|c|}{ （株）マクロミル } \\
\hline 公演内容 & 演劇 & ロック & クラシック & 伝統芸能 & 映画 & お笑いライブ & 寄席 \\
\hline 有効回答数 & 266 名 (男 78+女 188) & 334 名(男 148+女 186) & 345 名(男 150+女 195) & 211名(男 84+女 127) & 100 名 (男 51+女 49) & 105 名 (男 42+女 63) & 105 名 (男 73+女 32) \\
\hline 調査対象施設 & 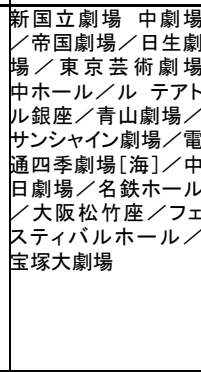 & 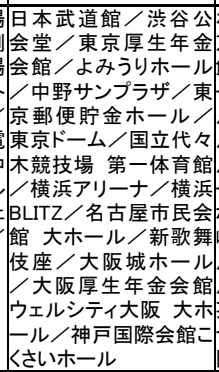 & 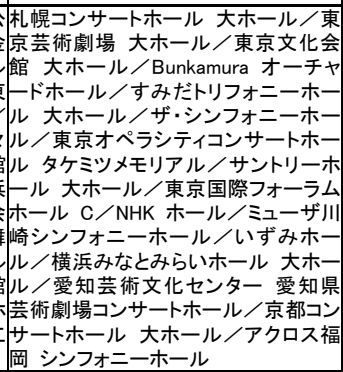 & 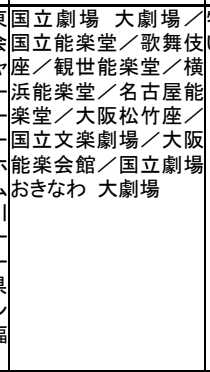 & & 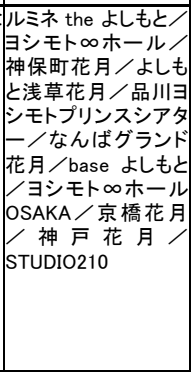 & 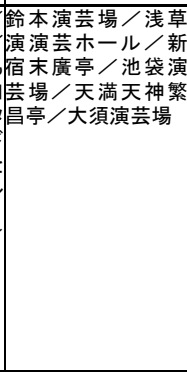 \\
\hline $\begin{array}{l}\text { 調査対象者 } \\
\text { 抽出方法 }\end{array}$ & $\begin{array}{l}\text { 上記劇場·ホールにお } \\
\text { て 15〜 30 名程度を回 }\end{array}$ & $\begin{array}{l}\text { 方ける「公演内容」欄|に示 } \\
\text { | 収目標として利用経験者 }\end{array}$ & $\begin{array}{l}\text { Lた演目の鑑賞経験を予備調査によ } \\
\text { 等抽出 }\end{array}$ & & $\begin{array}{l}\text { 過去 } 1 \text { 年間の映画館利用 } \\
\text { 者を予備調査により抽出 }\end{array}$ & $\begin{array}{l}\text { 上記劇場の利用経験 } \\
\text { 握し,「公演内容」別I }\end{array}$ & 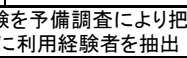 \\
\hline
\end{tabular}

\section{2 研究の構成}

本研究は, 大きく分けて 2 つの検討課題で構成されている。

まず，お笑い劇場の利用者像，お笑い劇場利用者のニーズを明確 にするための検討課題として「課題 1 ：類似施設との比較による利 用様態およびニーズの違い」を設定する。お笑い劇場利用者の主な 利用様態や劇場に対するニーズを，お笑い劇場のみの調査結果から ではなく類似施設との比較を通して，より明確化することを狙う。

類似施設の利用者像を把握するためには，主たる演目内容が音楽 や演劇のために用いられる劇場・ホール，および映画館を対象とし て行われた既存のアンケート調查を用いる。これら既存データと比 較可能な項目を用いて新たにお笑い劇場の調查を行ない, 利用者像 把握のための分析を行う（4 章）。

次に, 劇場周辺における鑑賞前後の具体的な行動や, 劇場周辺に おける行動のしやすさが集客力に与える影響を検討するために「課 題 2 : 鑑賞前後の利用者行動に関する分析」を設定する。課題 1 の 検討を踏まえてお笑い劇場の利用者, および比較対象として映画館 の利用者に対して新たにアンケート調查を行い, 具体的に劇場周辺 でどのような行動をしているのかという実態の把握, および, 各劇 場の集客力の指標として再訪意向を取り上げ，劇場周辺環境の影響 について検討する（5 章）。

本報で扱うお笑い劇場は, 表 1 , 表 3 の通りである。また, お笑 い劇場の種別を次のように分類している。

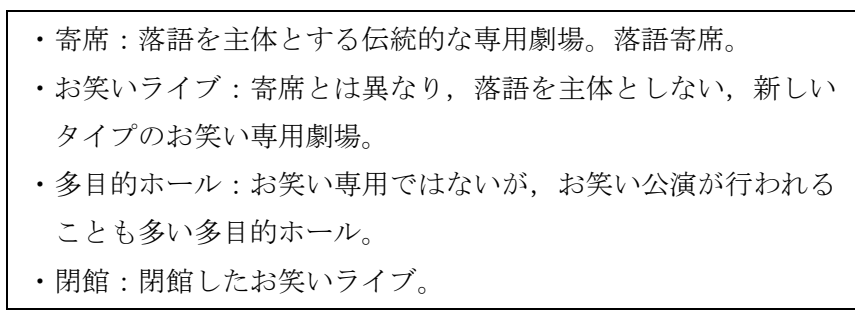

寄席は建築様式的には歌舞伎や能など伝統芸能のための劇場に近 い性格も持つ一方で，お笑いライブに出演する芸人が寄席に出演す ることも多く, 公演内容からは明確な峻別が難しい。そこで, 大き な分類においては寄席をお笑い劇場に含めておき, 必要に応じて両 者の利用者像や利用者行動の違いを検討することとする。

\section{4. 課題 1：劇場種別による利用様態およびニーズの違い}

\section{1 既存データの調査概要}

本章で用いる既存データは，「劇場・ホール利用者調査」，
画館利用者調査」の 2 種の調査に基づいている。両調査の概要を表 1 に示す。「劇場・ホール利用者調査」は全国 54 の劇場・ホールに 関する CS 調查として行われたものである。調查対象劇場は「演劇・ ロック・クラシック・伝統芸能」の公演によく使用される劇場が選 定されている。回答者は各劇場について鑑賞経験のある観客 20 名 程度（予備調査により抽出）, 計 1156 名のデータである。「映画館 利用者調査」は主要な設問を「劇場・ホール利用者調査」に準じて 設計した, 映画館利用者（有効回答 100 名）に対する調查である。 利用する映画館を特定していない点が「劇場・ホール利用者調査」 とは異なる。

本章の分析では，これら調査における利用様態に関する設問およ び重視度に関する設問を用いる。

\section{2 お笑い劇場利用者調査の概要}

お笑い劇場利用者を対象とした調查は，比較対象である既存デー 夕の質問項目を踏襲し, 項目設計を行なった。既存データと統合し た分析や施設種別による比較を可能とするためには，極力，同一の 項目で調查を行う必要がある。その一方でお笑い劇場の利用者に固 有の（既存調查においては調べられてはいない）ニーズ項目がある とすれば，調查項目に採用すべきと考える。そこで予備調査として， 早稲田大学のお笑い劇場を利用したことのある学生 20 名に, お笑 い劇場に対してどのような点を重視するのかということを自由記述 で回答してもらった。結果として「チケット料金」や「公演内容」 を重視しているという回答が多く把握されたため, 本調查の重視度 項目を設計する際にこの項目を取り入れている。

対象者の抽出方法や調査の実施方法は既存データを踏襲している。 「お笑いライブ」系劇場利用者 105 名, 「寄席」利用者 105 名, 計 210 名の有効回答を得た注 6 )。

\section{3 劇場利用様態に関するパターン分類}

本節では, お笑い劇場利用者の劇場利用様態を, 類似施設と比較 しつつ, その特徵を把握するため, 表 1 に示す 3 つの調査を統合し, 劇場・演目種別（お笑いライブ, 寄席, ロック, クラシック, 演劇, 伝統芸能, 映画館) ごとの計 1463 名のデータを用いて分析を行う。 劇場・演目別に回答者の年齢層の分布を図 2 に示す。

ここでの分析には, 回答者属性および「誰と, どのような理由, どのような状況で」劇場へ訪れているのかを MA（マルチアンサー） 形式で聞く設問（の選択肢を表 2 に示す）を用いる。

劇場・演目別に利用者の主なボリューム層を把握するために，劇 
場・演目種別, 年齢層, 性別をアイテム・カテゴリー型変数, 利用 様態の MA 式設問の選択肢を $0-1$ 型変数として, 数量化亚類を適用し た。2 次元までのサンプルスコア（寄与率：第 1 軸 $8.5 \%$ 第 2 軸 7. $4 \%=$ 累積 15.9\%) を用いて k-means 法によるクラスター分析を実 施し, 回答者を 5 つのクラスターに分類した。分析結果をまとめて 図 3 に示す。図 3 から, 以下の事項が読み取れる。

・5つのクラスターは, 利用様態別に見ると, I 家族サービスのた め配偶者と劇場を訪れる層\}，II 一人で，もしくはデートのつも りで劇場へ訪れる層\}, III \{演者のファンで友人・知人と訪れる層 \}, IV \{誘われて, 招待されて, 友人との親睦を兼ねて劇場へ訪れる層 $\},$ $\mathrm{V}$ 教養・後学のため, 雾囲気を楽しむために劇場一訪れる層\}に 分けられる。

・劇場・演目種別ごとにみると\{お笑いライブとロック $\}\{$ クラシッ クと伝統芸能 $\}$ 映画館と寄席 $\}$ の利用様態が類似している。

・お笑いライブ，ロック，演劇は，クラスターIII, IVの利用者層が 多く同伴者との親睦も兼㸚て利用されることが多い。

・男性と女性で劇場の利用状況に違いがある。

・お笑いライブは女性, 寄席は男性が多い。

以上の結果から, お笑いライブ系劇場は, 若い年齢層の女性が友人之 訪れ，同伴者との親睦も兼㸚て利用することが多く, 寄席系劇場は男性 が一人もしくは配偶者と, 趣味の鑑賞のために訪れることが多い劇場で あることがわかった注7)。同じお笑い公演を行う劇場でも, お笑いライブ系 の劇場と寄席では利用者層・利用様態はかなり異なるようである。

\section{4 重視度に関する基礎的分析}

次に, お笑い劇場利用者の重視度について分析を行う。 重視度の設問は 5 段階評価（重視する (5)〜全く重視しない (1)） であり，項目内容は分析結果とともに図 4 に示寸。

お笑い劇場利用者（お笑いライブ利用者と寄席利用者のデータを 統合したデータ）の重視度データに対して因子分析を適用し，お笑 い劇場のニーズの類型化をはかる。因子分析（最尤法，5因子，ク
オタミン回転解）の結果を, 各劇場利用者層の重視度の評価平均值 とともに図 4 に示す。得られた因子の解釈を以下に記す。

$\mathrm{F} 1$ : 施設環境 (照明・採光, 空調, 通路幅)

$\mathrm{F} 2$ : 施設の利用しやすさ（トイレ，ロビー, 売店，）

F $3:$ 鑑賞満足 (舞台が見やすさ, 公演内容, 座席の配置)

F 4 : アクセス・デザイン（劇場のアクセス, 劇場のデザイン）

F 5 : 周辺環境（劇場に着くまでの気分, 劇場周辺の雰囲気）

次に, 劇場種別による各層の重視度に関する評価平均が, お笑い 劇場の利用者層の平均と異なるのかダネット検定注8) を行う。お笑 いライブの平均值が他の層より有意に高い（重視側）かどうかを問 題としたいため片側検定として, 検定結果を図 4 中に㶰印で示す。 図 4 より，次の事実を読み取れる。

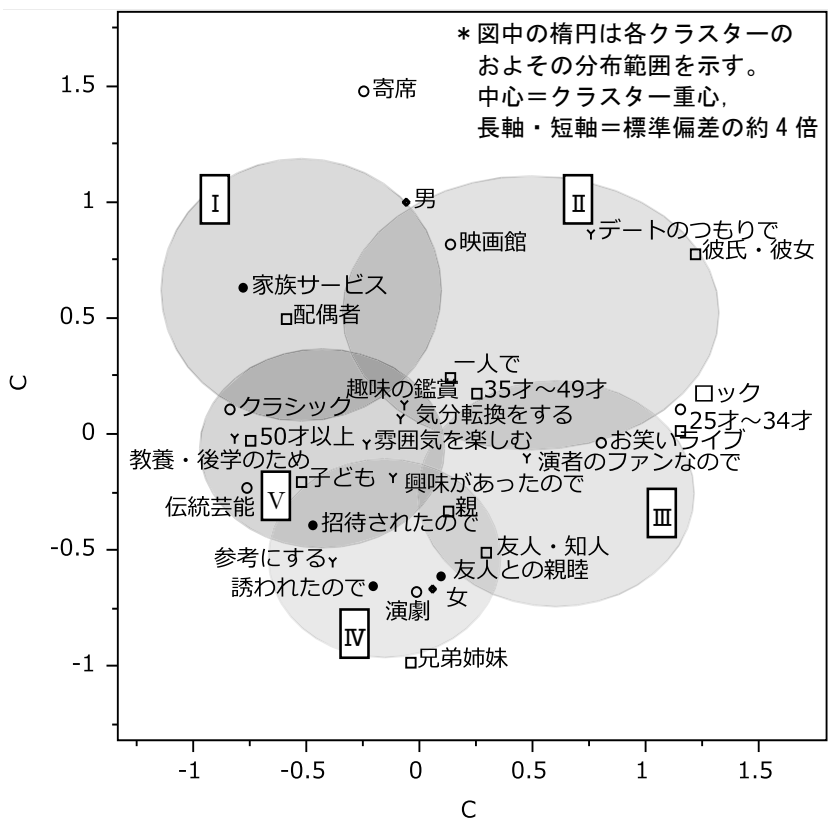

図 3 利用様態に関する数量化III類およびクラスター分析

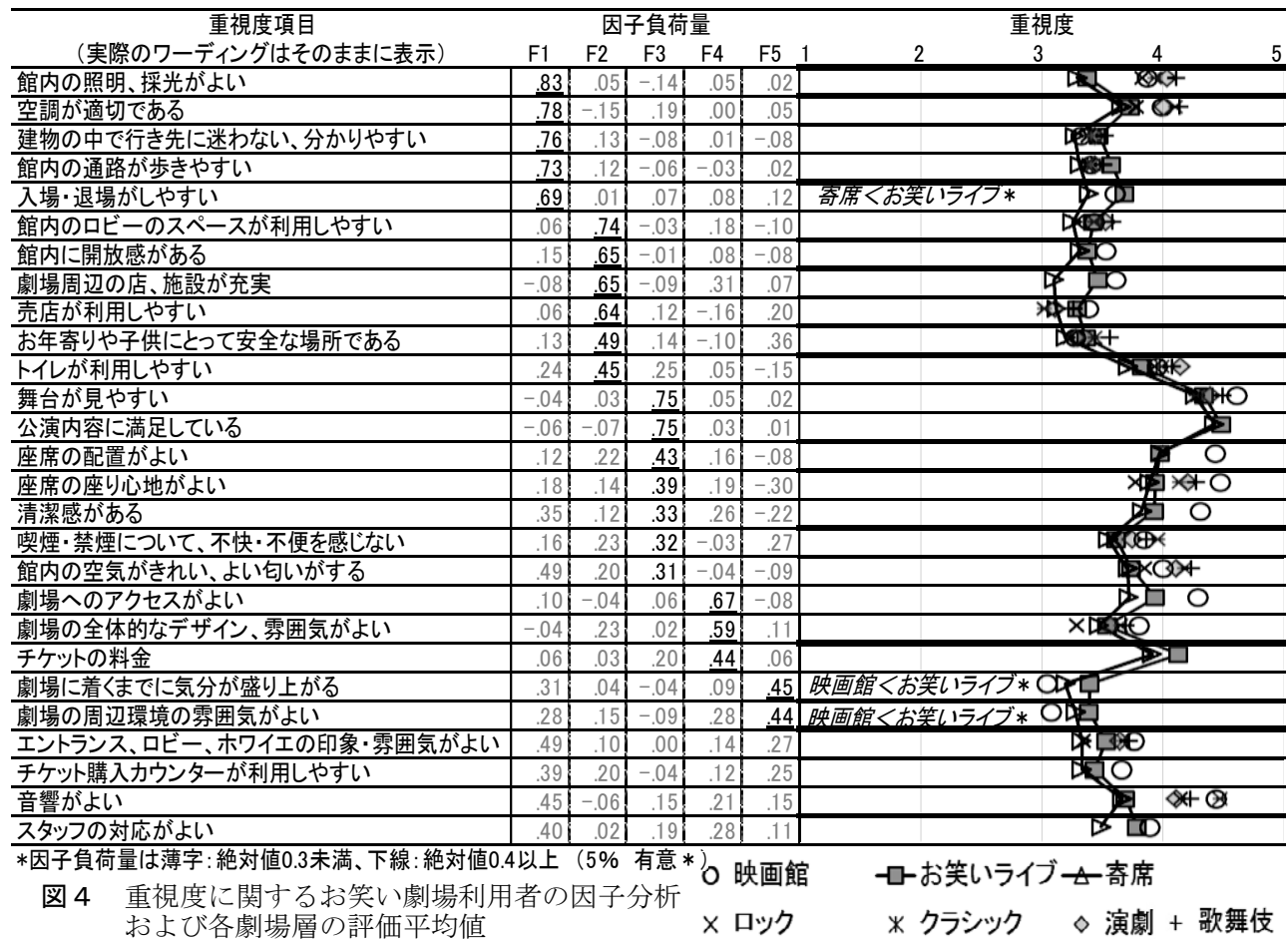

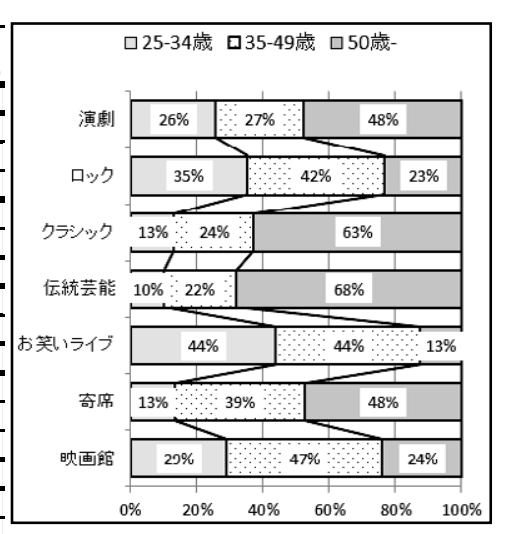

図 2 劇場 $\cdot$ 演目別年齢層

表 2 利用様態に関する選択肢 誰 自分一人で/友人·知人/彼氏·彼女/配偶 と 者/子供 $/$ 兄弟 趣味の鑑賞のため/演者のファンなので／話 理 題の公演なので/興味があったので/息抜 由き, 気分転換をするため/雾囲気を楽しむた

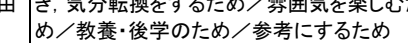
デートのつもりで/家族サービスとして/友人 との親睦もかねて/旅行·観光の一環として/ 状 チケットをもらった，招待されたので/誘われ 況 たので/つきあい.義理で/何となくふらりと/ 買い物や何かのついでに 
・「F3 : 鑑賞満足」に関わる項目はどの層も重視度評価が高い。

・「F5：周辺環境」に関わる項目の重視度は「映画館＜寄席＜お笑 いライブ」となっており，特にお笑いライブと映画館の差はダネ ット検定においても有意となった。

\section{5 本章のまとめ}

本章の分析・考察を総括する。お笑い劇場を含めて各種演目内容 別劇場系施設は, その種別によって利用者層・利用様態が異なるこ とがわかった。お笑いライブ利用者は，劇場を友人との親睦も兼㸚 て利用することが多い。従って，劇場周辺における鑑賞前後の行動 も「親睦を兼ねた」行動が予想される。また，お笑いライブ利用者 は, 他の劇場系施設の利用者に比べて, 劇場周辺の環境の重要度が 高い。

\section{5. 課題 2 : 鑑賞前後の利用者行動に関する分析}

\section{1 調査データの概要}

本章では, 前章の結果をふまえて新たに調査を実施し, 鑑賞前後 の利用者行動の実態把握および集客力への影響を検討する。調査の 概要を表 3 に示す。劇場種別ごとの有効回答者の年齢層の分布を図 5 に示寸。「映画館利用者行動調査」は，「お笑い劇場利用者行動調 查」と比較するために実施した（比較可能なように調查を設計して いる)。比較対象として映画館を選んだのは, 前章の分析から, 映画 館とお笑いライブの利用者は利用様態やニーズの点で違いが大きく また，設備等のハードの点でも違いが大きいことから，比較的明確 な違いが把握されることを狙ったものである。

これら調查は表 3 に示した施設に対する CS 調查の形式で実施し ており，一般的な満足度等の調査項目も含む。本章では，鑑賞前後 の行動を問う自由記述式の設問, および集客力の指標として各施設 に対する再訪意向, および各劇場およびその周辺における各種行動 のしやすさを評価する設問を分析に用いる。

\section{2 鑑賞前後の行動に関する自由記述の分析}

お笑い劇場および映画館の利用者が具体的には鑑賞前後にどのよ うな行動をしているか，自由記述式の設問から鑑賞前後の行動を把 握する。この設問では「この劇場（映画館）でお笑い（映画）を鑑 賞する前後に, どのような行動をしていますか。」という質問文に 対し，「鑑賞前」「鑑賞後」に分けて自由記述式回答を求めている。

得られた記述を分類整理し, 得られた主要な行動, 具体的な記述 例, および集計結果(鑑賞前後および映画館/お笑い劇場別に, 記述 数を回答者数で除した相対度数, および映画館とお笑い劇場の間の 母比率の差の検定）を表 4 にまとめて示す。

表 35 章の分析に用いる調查の概要注 9)

\begin{tabular}{|c|c|c|c|c|c|}
\hline 調査名称·時期 & \multicolumn{4}{|c|}{ お笑い劇場利用者行動調査 (2012.3 および 2012.10 の 2 回にわけて実施) } & \multirow[b]{2}{*}{ シネマコンプレックス ${ }^{\text {i } 10}$} \\
\hline 施設種別 & お笑いライブ & 寄席 & 多目的ホール & 閉館(2 回目調査のみ) & \\
\hline 有効回答数 & $\begin{array}{c}319 \text { 名 } \\
\text { (男 138+女 181) }\end{array}$ & $\begin{array}{c}160 \text { 名 } \\
\text { (男 } 113+\text { 女 47) }\end{array}$ & $\begin{array}{c}160 \text { 名 } \\
\text { (男 } 50+\text { 女 110) }\end{array}$ & $\begin{array}{c}210 \text { 名 } \\
\text { (男 } 90+\text { 女 } 120 \text { ) }\end{array}$ & $\begin{array}{c}320 \text { 名 } \\
\text { (男 159+女 161) }\end{array}$ \\
\hline 調查対 & 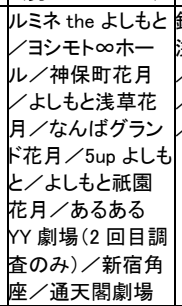 & \begin{tabular}{|l} 
鈴本演芸場／ \\
浅草演芸ホール \\
新宿末廣亭 \\
池袋演芸場 \\
国立演芸場
\end{tabular} & 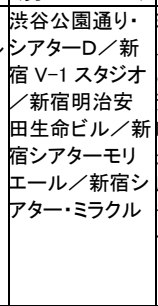 & 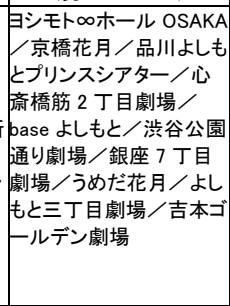 & 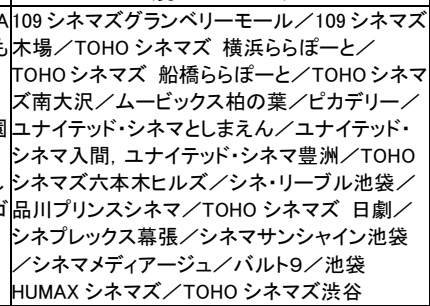 \\
\hline & & & & & の柇 \\
\hline
\end{tabular}

「食事」「買い物」「散策」「観光」について映画館とお笑い劇場の 間で該当する記述の生起率を検定し，「食事」「散策」「観光」は鑑 賞前後ともお笑い劇場利用者の方が映画館利用者より高頻度である ことが把握された。お笑い劇場利用者はこれらの行動を劇場周辺で 行うことが多いようだ。しかし，「買い物」については，鑑賞前は 有意差がなく，鑑賞後は映画館利用者の方が有意に大きい。今回調 査対象とした映画館は商業施設に併設されることが多いシネマコン プレックス注10) のタイプであるから，物理的に買い物しやすい環境 であることも一因であろう。

「食事」「買い物」などの具体的な記述例をみてみると, 同じ「食 事」行動でも，お笑い劇場と映画館では内容・動機が異なる場合が ある。映画館利用者の食事に比べるとお笑い劇場利用者は, 芸人が 紹介していた店で食事をしていたり，鑑賞後の食事によってお笑い 公演の余韻を楽しんでいるなど，公演と関連させた内容であること がわかる。このことから，映画館における周辺行動は商業施設とい う環境による要因が行動発生につながっており, お笑い劇場は, お 笑い公演を劇場周辺における行動との一連のプロセスで楽しみたい といらニーズによる行動発生であると考えられる。

さらに, 行動の内容を問わず,「鑑賞前後に何らかの行動をする人」を 集計すると, お笑い劇場利用者全体の $80.6 \%$, 映画館利用者では全体 の $77.1 \%$ であった。この差は有意ではないが, わずかにお笑い劇場利用 者の方が鑑賞前後の行動が多い。いずれにしても, 劇場に直行・直帰す る人は少数派であり, 何らかの行動をする人が多数派であるといえる。特 に鑑賞後は食事をする人が過半数(お笑い劇場では $66.1 \%$ )であり, 食 事は鑑賞後の行動として定着しているといえる。

表 4 鑑賞前後の利用者行動の分類・集計注 11$)$

\begin{tabular}{|c|c|c|c|c|c|}
\hline \multirow{2}{*}{ 行動 } & \multirow{2}{*}{$\begin{array}{c}\text { 記述例 } \\
\text { ([笑]：お笑い, [映]:映画館,無印:両方) }\end{array}$} & \multicolumn{3}{|c|}{ 相対度数 } & 検 \\
\hline & & & 映画館 & お笑い & 定 \\
\hline \multirow[t]{2}{*}{ 食事 } & \multirow{2}{*}{$\begin{array}{l}\text { 芸人が紹介していた店で食事／公演の感想を } \\
\text { 楽しみながら食事 [笑] 映画館周辺のお占で } \\
\text { 昼食 [映] }\end{array}$} & 前 & $34.1 \%$ & $45.7 \%$ & ** \\
\hline & & 後 & 52. $2 \%$ & $66.1 \%$ & * \\
\hline \multirow[t]{2}{*}{ 買い物 } & \multirow{2}{*}{$\begin{array}{l}\text { ルミネで買い物／差し入れを買う[笑]，アウ } \\
\text { トレットで買い物／マルイで買い物 [映] }\end{array}$} & 前 & 22. $2 \%$ & $25.7 \%$ & ns \\
\hline & & 後 & $30.6 \%$ & $15.4 \%$ & k* \\
\hline \multirow[t]{2}{*}{ 散策 } & \multirow{2}{*}{$\begin{array}{l}\text { 劇場周辺のお店や街並みをぶらぶら見て歩い } \\
\text { たこノ雾囲気を楽しみながら散歩 }\end{array}$} & 前 & 10. $0 \%$ & 22. $0 \%$ & $*$ \\
\hline & & 後 & 5. $6 \%$ & $10.6 \%$ & ** \\
\hline \multirow[t]{2}{*}{ 観光 } & \multirow{2}{*}{$\begin{array}{l}\text { 通天閣, 浅草寺など観光地に行く/浅草やア } \\
\text { メ横で観光してから劇場に行く }\end{array}$} & 前 & $0.9 \%$ & $6.8 \%$ & * \\
\hline & & 後 & $0.0 \%$ & 2. $7 \%$ & . \\
\hline \multirow[t]{2}{*}{ 出待ち } & 芸人さんの出待ちをする/ファンレター & 前 & & & \\
\hline & を渡すために出待ちした [笑] & 後 & & 2. $2 \%$ & \\
\hline \multirow[t]{2}{*}{ 遊び } & 友達とプリクラを撮りに行ったノゲームセン & 前 & $1.9 \%$ & $5.9 \%$ & \\
\hline & ターに行った & 後 & $5.0 \%$ & $3.1 \%$ & \\
\hline
\end{tabular}

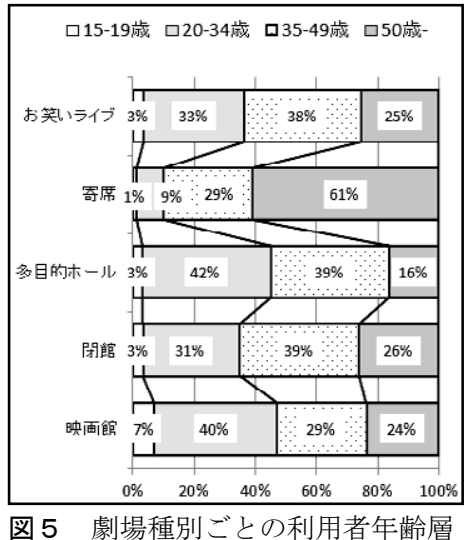




\section{3 行動のしやすさに関する統計的因果分析}

本節では，劇場周辺において各種の行動がしやすいことが劇場へ の再訪意向にどのような影響を与えるのか検討する。

再訪意向は「この劇場にまた行きたい」という質問に「そう思う (5)〜そう思わない(1)」の 5 段階で回答を求めており，これを集客 力の指標と考える。劇場周辺における行動のしやすさについては, 食事や買い物などの行動について「しや寸い(5)〜しにくい(1)」の 5 段階評価を求めている注 ${ }^{12)}$ 。また, その他の CS 調査項目の中か ら, 劇場周辺での行動に関連する評価項目として, 「劇場に着くま でに，盛り上がりやすい」「劇場を出た後も，盛り上がりやすい」 「劇場を出た後も, 余韻に浸りやすい」の 3 項目（これらも満足側 を 5 とする 5 段階評価である）を取り上げ，各種行動のしやすさと 再訪意向をつなぐ中間変数として位置づける。

これら設問の間に， \{各行動のしやすさ $\} \rightarrow\{$ 余韻や盛り上がり $\}$ $\rightarrow\{$ また行きたい\} という因果順序を想定し, 統計的因果分析を行 なった。お笑い劇場の調査データ注 ${ }^{13)}$ に対する分析結果を図 6 , 映 画館の調査データに対する分析結果を図 7 に示す。

なお，「劇場に着くまで」と「劇場を出た後」の「盛り上がりや すい」を調查票においては別々に評価しているが，両者の相関は高 かったので，平均值を用いて合成変数化し，1つの変数として扱っ ている。「盛り上がりやすい」「余韻に浸りやすい」の間の因果関係 については，誤差相関を含めた可能なモデルでSEM を実行し，最も 適合度の高いモデルを採用している。適合度は良好であり，モデル に含まれるパスは全て有意である。

この結果から, 各行動のしやすさは周辺環境での「盛り上がり」 や「余韻」へとつながり「また行きたい」に影響しているというこ とがわかり，周辺環境の行動しやすさが，劇場の再訪意向に影響を 与えていることが把握された。図 $6 ， 7$ を見比べると，お笑い劇場 の方が映画館より，各行動が盛り上がりや余韻へと働きかけている ことがわかる。また再訪意向「また行きたい」の決定係数もお笑い 劇場の方が高く（お笑い=0.17, 映画館=0.11），各行動のしやすさ が再訪意向に影響を与えているということがわかる。

さらに, 映画館は「買い物のしやすさ」が周辺環境での「余韻に浸りや すい」へネガティブに働きかけ，「また行きたい」に負の影響を与えている。 映画館にとって買い物とは鑑賞行為の後押しをするような要因には ならないようである。映画館の利用者行動について追求することは 本研究の主旨ではないが，考えられる事態を考察しておく。前節の 考察でもふれたが，本調査の対象映画館はシネマ・コンプレックス であり，商業施設に併設あるいは隣接していることから，買い物す る人も多くなる。しかし，映画の内容とは無関係の「ついで」に行 う買い物行動は，むしろ鑑賞の余韻をかき消し現実に戻してしまう 効果も持ってしまっている可能性がある。

\section{4 本章のまとめ}

鑑賞前後の利用者行動を映画館利用者との比較から，お笑い劇場 利用者は鑑賞前後に食事や散策など何らかの行動をする人が多数派 であり，その行動のしやすさが劇場への再訪意向に影響を与えてい るということがわかった。

\section{6. まとめ}

本論文の成果を総括する。お笑い劇場の利用者行動を以下に示す。
・お笑いライブ系の劇場は, 若い女性が友人との親睦を兼ねて利用 することが多い劇場である。

・お笑い劇場利用者は，鑑賞の前後に食事や散策などの行動をする 人が多数派であり，鑑賞後は食事で余韻を楽しんでいる。

・お笑い劇場の周辺環境における各種行動のしや寸さは，劇場の再 訪意向に影響を与える。

これらの結果から，利用者はお笑い劇場に対して，公演内容のみ を楽しむのではなく劇場の周辺環境も楽しめることを期待しており， 劇場にはお笑い公演を前後の行動との一連のプロセスで楽しめる環 境を求めていると考えられる。今後の課題としては, 個々の劇場に 対する評価を行なっているため, 個々のお笑い劇場の行動しや寸さ がどのように評価されているのか, お笑い劇場利用者をタイプ分類 し，利用者層によって再訪意向に影響を与え行動には違いがあるの か, 鑑賞前後の行動には違いがあるのか, お笑い劇場利用者の周辺 環境による利用者行動をより詳しく検討していきたい。

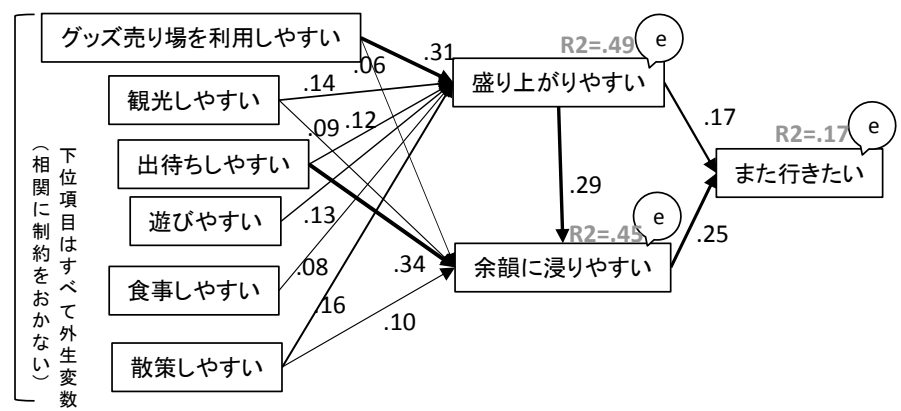

$(\chi 2=17.22, \mathrm{df}=8, \mathrm{p}=2.8 \%, \mathrm{RMSEA}=0.037, \mathrm{GFI}=0.996)$

図 6 お笑い劇場周辺における行動しや寸さに関する因果モデル

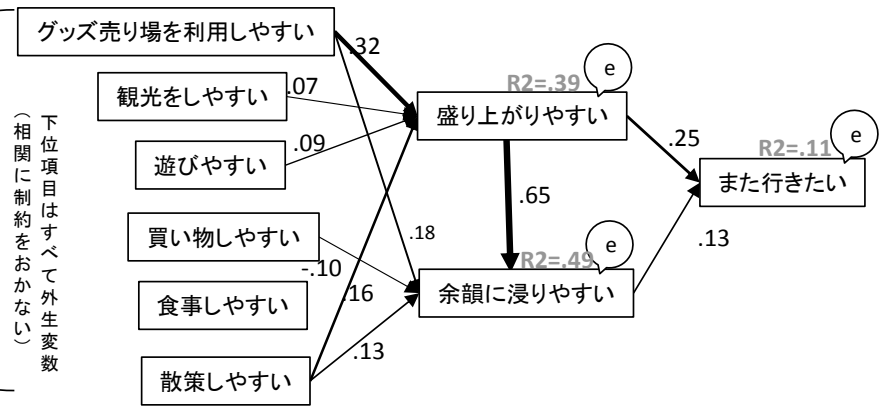

( $\chi 2=12.57, d f=11, p=32.3 \%$, RMSEA=0. 021, GF I=0. 992)

図 7 映画館周辺における行動しやすさに関する因果モデル

\section{謝辞}

本研究では，文部科学省私立大学戦略的研究基盤形成支援事業に より費用の一部を支出した。ここに謝意を表します。

映画館の調查は山際恒太氏, 山崎洋輔氏（当時早稲田大学人間科 学部）の卒業論文として行ったものです。小野久美子氏（(独)建築 研究所)には未公表の調査データの使用を承諾していただきました。 上野佳奈子氏（当時東京大学生産研究所, 現在明治大学) には上記 調查の実施段階で多大なご協力をいただきました。お笑い劇場を所 有・運営する会社の S 氏 (社名・個人名は控えさせていただきます), 放送作家山本太欧氏 (早稲田大学人間科学部在学中), お笑い芸人の AKI 氏, 加藤氏（㑣ベンヌ, コンビ名門出ピーチクパーチク）には インタビュー調查にご協力いただきました。

本研究にご協力いただいたみなさまに謝意を表します。 
付録

5. 3節で用いた統計的因果分析（SEM）は共分散行列から実行できる。そ こで, 他の分析者による検証・反証・発展の可能性という見地から，本論文 末尾に付表 1 として，共分散行列を掲載する。

\section{注}

注 1 ）本論文は，山本・小島 ${ }^{1 ）}{ }^{2)}$ の内容をもとに分析・考察をあらため再編 したものである。

注 2 ）「出待ち」「追っかけ」の意味は次の通り。

【出待ち】劇場，放送局，スタジアムなどの出入りロで，ファンが目当て の芸能人や有名選手などの出てくるのを待っていること。(デジタル大辞 泉より)，【追っ掛け】有名人の行くところ行くところを追いかけてゆく熱 狂的なファン。(大辞林 第三版 (三省堂) より)

注 3 ）例えば，吉本興業は，飲食店の情報を集めたウェブサイトの運営をす る株式会社ぐるなびと提携し「よしもとぐるなび」のサービスを開始し， 芸人が打す寸めするグルメ情報として劇場周辺の飲食店を紹介している。

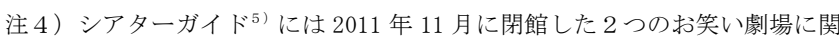
して, 集客が奮わなかった背景に震災（東日本大震災）の影響も指摘され ている。しかし震災以前にも多くの劇場が閉館していることから，震災の 影響は震災直後に閉館となったいくつかの劇場にのみ該当する閉館要因と 考えられる。

また，閉館の多さやその原因に関するここでの記述は，他の類似施設に も同様の状況が当てはまる場合があるかもしれず，お笑い劇場に限った特 徴とは考えていないことを附記する。

注 5 ) 筆者らは打笑いライブの企画・運営関係者を対象とした意識調查を別 途進行中であり，本稿執筆時点までにお笑い劇場を所有，運営する会社の 社員 1 名, お笑い芸人 2 名, お笑いライブを企画する放送作家 1 名にイン タビュー調查を行っている。本文中の記載事項はこれら調查の中で付随的 に把握された内容である。

注 6 ） 4 章で用いる調査の出典・手続き等を補足する。いずれも全国 25 歳以 上の調查会社モニター登録者を対象に予備調査を行い, 本調查の対象者を 抽出したインターネット調査である。調查会社の吸収・合併などで会社名 は変更しているが，すべての調査は同一系統の調査会社を利用しており， モニター登録者も引き継がれている。以下，個別の調查について。 (1)劇場・ホール利用者調查

小野・小島ほか ${ }^{6)}$ から継続する「公共施設に関する CS 調查活動」に関す る研究課題の一環として, 国土交通省国土技術政策総合研究所および独立 法人建築研究所により共同で実施した調查である。公演内容の分類（ロッ ク：ロック・歌謡などのコンサート/クラシック：声楽, クラシック音楽 などのコンサート/演劇 : オペラ, 演劇, ミュージカルなど/伝統芸能 : 歌舞伎, 能, 狂言, 文楽, 舞踏など日本の伝統芸能) は, 元々は小野・小 島ほか ${ }^{6)}$ の予備調查における設問のワーディングとして用いられたもので ある。調查対象劇場の選定にあたっては，建築音響の研究者に協力を依頼 して専門的知見に基づき公演内容ごとに候補をリストアップし，さらに当 時の「公共施設に関する CS 調査活動」の経緯による事情を加味して, 74 の候補劇場を選定した。

小野・小島ほか $\left.{ }^{6}\right)$ の予備調查 $(2005.9$ 実施 $)$ では, 各公演内容ごとに鑑 賞経験を「まったく行かない・何度か行った・たまには行く・ときどき行 く・よく行く」の 5 段階で回答を求めている。ここで少なくとも 1 つは「た まには行く〜よく行く」と回答した人をこの調査における予備調査の対象 者としている(発信 5069 名, 有効回答 3661 名)。予備調查の設問は, まず, 小野・小島ほか $\left.{ }^{6}\right)$ 同様の選択肢により公演内容ごとの鑑賞経験を聞き，「た まには行く〜よく行く」と回答した場合には前述の調查対象候補劇場につ いて利用経験をMA 形式で回答を求めるというものである。その結果に基づ き, 候補劇場のうち利用経験者が多い54 劇場を本調査の対象劇場として選 定し，各劇場の利用経験者を本調查の対象者として抽出した。 (2)映画館利用者調查

「山際 恒太 : 映画館の魅力と不満に関する意識調查，早稲田大学人間科 学部卒業論文, 2010.1」の一環として実施された調查であり，学会論文等 としては未公表である。予備調查は庄司・小島 ${ }^{11)}$ における調查 1 の予備調 查を兼㸚て実施しており，庄司・小島 ${ }^{11)}$ の注釈 3 ）なども参照されたい。 16500 名に配信し，5000 名の回答を得た時点で回収打ち切りとし，過去 1 年間に映画館に「よく行く」「ときどき行く」，その回数を「5〜9 回」「10
〜20 回」「20 回より多い」と答えた回答者を本調査の対象とした。 (3)笑い劇場利用者調查

予備調査は他のいくつかの調査の予備調査を兼ねる共同調査の形で実施 している。配信数は自動制御（具体的数值は不明だが，回収率分母が大き くならないように段階的に配信コントロール ${ }^{12)}$ を行う)，有効回答 20000 名を得た。17 のお笑い劇場（お笑いライブや寄席）を提示し，「よく行く」

「何度か行ったことがある」と答えた回答者のなかから，よく行く劇場が お笑いライブの回答者，および寄席の回答者を，極力重複を避けて本調査 の対象として抽出した。

注 7 ）ここでの分析は利用者像の典型化・類型化であり, 利用様態の違いが 何に起因するかという因果関係については言及していない。考えられる因 果グラフを図 8 に示寸が,

（a）属性により利用様態が異なる。同じ属性ならば，劇場種別により利用 様態は変わらない。（若い女性は寄席にも「友人と親睦を兼ねて」行く）

（b）劇場種別により利用様態が異なる。同じ種別の劇場においては，属性 による利用様態の違いはない。（若い女性でも寄席には「一人で趣味の鑑賞 のために」行く)

（c）利用様態は劇場種別と属性の両方の影響を受ける。（若い女性はどこに 行くにも「友人と親睦を兼祇て」が多いが，寄席に行くときは「一人で趣 味の鑑賞のために」が多少増える)

という関係の，いずれの可能性も否定できない。なお，上記説明の括弧内 の例示における条件節「若い女性が寄席に行く」という状況自体が少数派 (ボリューム層ではない) であることを附記しておく。

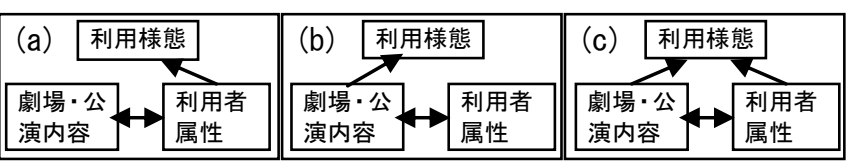

付図 1 利用様態に関寸る考えられる因果関係のパターン

注 8 ）ダネット検定とは, 通常, 複数の処理群と 1 つの対照群の間で平均值 の比較を行うための多重比較検定として用いられる。ここでは処理群・対 照群という用語には語弊があるが，お笑いライブを対照群，その他の層を 処理群として扱い，お笑いライブとその他の層の間の差を検定する。

注 9 ） 5 章で用いる調査の出典・手続き等を補足する。いずれも調査会社は （株）マクロミル，15 歳以上のモニター登録者を対象に予備調査を行うイ ンターネット調査である。

(1)求笑い劇場利用者行動調査

1 回目の調査は表 3 中の「お笑いライブ」「寄席」「多目的ホール」欄内 の 19 劇場を対象とし，2回目の調査は「閉館」10 件および新設の「お笑 いライブ」 1 件を追加して 30 劇場を調査対象劇場とした。これら劇場の所 在地近隣の都道府県（東京・埼玉 ・千葉・神奈川・大阪・兵庫・京都・岡 山・福岡) に居住する 15 歳以上のモニター登録者を対象に予備調査を実施 し, 1 回目: 10000 名, 2 回目 : 30000 名の有効回答を得た（配信はいずれ も自動制御)。各劇場でのお笑い公演鑑賞経験を「 1 回もない・1 回はある・ 2 4 回・5 9 回・10 20 回・20 回より多い」という選択肢で問う設問の 結果に基づき，利用経験者が多い劇場では「2〜4回」以上，利用経験者が 少ない劇場では条件を緩和し「1 回はある」以上の選択肢を選んだ回答者 を本調査の対象とした。1 回目の本調査では各劇場 15 名（一部 30 名），2 回目の本調査では「閉館」は各劇場 20 名, その他の種別は各劇場 15 名を 回収目標として調査を実施した。

(2)映画館利用者行動調査

「山崎 洋輔 : 複合商業施設の映画館における利用者行動研究, 早稲田大学 人間科学部卒業論文，2013.1」の一環として実施された調査であり，学会 論文等としては未公表。予備調査では首都圈（東京・埼玉・千葉・神奈川） の映画館 28 館（いずれもシネマコンプレックスのタイプである。所在地が 都心〜郊外・近隣県と分布するように，また，商業施設内に併設される夕 イプを中心に候補施設を選定した。）の利用経験を「(1)お笑い劇場利用者行 動調査」と同様の選択肢により各映画館の利用経験を調べている。首都圈 に居住する 15 歳以上のモニター登録者に配信，有効回答 10000 名を得て, 各館とも「 $2 \sim 4$ 回」以上の利用経験がある回答者を本調查の対象とした。 本調査では利用経験者が多い映画館を中心に 20 館を調査対象として選定し， 各館 15 名を回収目標として調査を実施した。 
注 10)【シネマコンプレックス】入場券売り場や売店などを共有する複数の映 画館が集合している施設。(大辞林 第三版（三省堂）より）

注 11）「出待ち」「遊び」は検定の対象から除外しているが，それは次のよう な理由による。まず，「出待ち」はお笑い劇場利用者のみの行動であり，映 画館利用者においては皆無である。出演者がいない映画館では「出待ち」 がありえないので, これは当然である。「遊び」に関しては,「食事」「散策」 「買い物」「観光」などの行動が「遊び」と表現される場合があり，「遊び」 とその他の行動の明確な区別は難しい。ここでの分類は明確な内容が記さ れていない遊び，および「食事」等の他の分類に該当しない遊びを「遊び」 としている。これはいわば「その他」に該当するカテゴリともいえ，1つ の群をなす母集団を仮定する検定の対象とするロジックにはなじまない。

注 12）行動しやすさと実際の鑑賞前後の行動に関しては,「お笑い劇場」 1 回 目および「映画館」の調查では, 鑑賞の前と後を分けた 15 項目の設問であ るが,「お笑い劇場」の 2 回目調査では, 1 回目の調査で鑑賞の前と後では 大きな違いが見られなかったことを踏まえ, 鑑賞の前後を分けず 10 項目の 設問としている。 5 . 3 節の分析において, 鑑賞前と後を分けている項目 は, 両者の平均值を求め, 調査 2 回目における鑑賞前後を分けない項目と 同一変数として扱っている。この扱いにより分析結果に大きな悪影響が生 じないことは検討・確認済みである。

注 13）まず 2 回の調査ごとに分析を行い, 両者に大差のない結果を得られる ことが確認された。また，お笑い劇場の調查対象の中にはお笑い専用では ない多目的ホールや寄席も含まれているが，これら劇場のデータを含めて も, 含めなくても大差のない結果であることを確認し, 寄席もお笑い劇場 として含めて分析を行なった。なお, 今回の調查対象劇場の中の劇場間比 較は本論文に続く続報その 2 にて報告寸る予定である。

\section{参考文献}

1) 山本杏子・小島隆矢 : お笑い劇場に関する利用者と非利用者の意識調査, 日本建築学会大会学術講演梗概集, D-1, pp75-76, 2011

2 ) 山本杏子 - 小島隆矢 : お笑い劇場の利用様態に関する研究 - 類似施設と の比較および鑑賞前後の行動に関する分析-, 日本建築学会大会学術講演 梗概集，E-1，pp289-290，2012

3 ) 増田昌文: 吉本興業の正体, 草思社, 2007.4

4 ) 岩田友幸, 岡本安善, 大悟法弘一：テレビお笑いタレント史, ソフトバ ンク株式会社, 2005.10

5 ）シアターガイド :「京橋花月」「品川よしもとプリンスシアター」が 11 月 で閉館に, http://www. theaterguide. co. jp/theater_news/2011/10/18_03. php (2011.10.20 参照)

6 ）小野久美子・小島隆矢・東海林伸篤・讃井純一郎：劇場, ホールにおけ る顧客満足度調查に関する研究 その 1 「観客」のニーズ把握について, 日本建築学会大会学術講演梗概集, D- 1, pp. 841-842, 2006.9

7 ) 遠山直子 - 添田昌志 - 大野隆造 : 劇場の周辺環境と鑑賞前後の行動との 関係, 日本建築学会大会学術講演梗概集, E-1, pp. 1127-1128, 2003.7

8 ) 坂口大洋 - 小野田泰明 - 菅野實 - 檜山智子 : 公演内容と利用者構成の関 係について 劇場利用圈のモデル構築に関する研究 その 1 , 日本建築学 会大会学術講演梗概集，E-1，pp. 179-180，1998.7

9 ）相田文・坂口大洋・菅野實 : 劇場利用の鑑賞行動と志向性について - 劇 場利用圈のモデル構築に関する研究 その 2-, 日本建築学会大会学術講 演梗概集， E-1，pp. 87-88，1999.7

10）坂口大洋・菅野實・岩下明久：劇場利用者個人の鑑賞意識と鑑賞行為に ついて -劇場利用圈のモデル構築に関する研究 その 3-, 日本建築学会 大会学術講演梗概集, E-1, pp. 89-90, 1999.7

11）庄司名奈恵・小島隆矢 : 公共図書館の利用阻害要因となるネガティブな 印象に関寸る研究, 日本建築学会環境系論文集, No.681, pp. 829-836, 2012. 11

12) 日本建築学会編: 住まいと街をつくるための 調査のデザイン, オーム社, 2011.3（２章 COLMN「インターネットリサーチ」参照）

付表 15.3 節の統計的因果分析で用いた変数の分散共分散（対角成分より左下：お笑い劇場，右上：映画館）

\begin{tabular}{|c|c|c|c|c|c|c|c|c|c|c|c|}
\hline & 散策 & 食事 & 買い物 & 遊び & 観光 & グッズ売り場 & 出待ち & 盛り上がり & 余韻に浸り & また行きたい & |分散(映画館) \\
\hline 散策しやすい & & 0.533993 & 0.466595 & 0.509111 & 0.410022 & 0.296826 & $\begin{array}{c}-- \\
-\end{array}$ & 0.328909 & 0.345905 & 0.152136 & 0.956260 \\
\hline 食事しやすい & 0.545804 & - & 0.615008 & 0.568378 & 0.413303 & 0.251959 & --- & 0.258915 & 0.229428 & 0.145964 & 0.875196 \\
\hline 買い物しやすい & --- & --- & 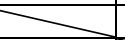 & 0.479350 & 0.263774 & 0.172335 & --- & 0.211579 & 0.151685 & 0.160384 & 0.777390 \\
\hline 観光しやすい & 0.578454 & 0.506672 & --- & 0.494108 & & 0.289303 & --- & 0.283924 & 0.297943 & 0.099158 & 1.044975 \\
\hline グッズ売り場 & 0.332262 & 0.287867 & --- & 0.248929 & 0.384719 & 7 & --- & 0.329114 & 0.362931 & 0.164028 & 0.727116 \\
\hline 出待ちしやすい & 0.207735 & 0.259701 & --- & 0.196153 & 0.246275 & 0.222719 & 3 & --- & -- & -- & --- \\
\hline 盛り上がりやすい & 0.445727 & 0.410382 & --- & 0.373216 & 0.484501 & 0.442546 & 0.274272 & 7 & 0.428507 & 0.189910 & 0.537608 \\
\hline 余韻に浸りやすい & 0.356707 & 0.290480 & --- & 0.264703 & 0.395062 & 0.323492 & 0.382584 & 0.443146 & & 0.203644 & 0.758582 \\
\hline また行きたい & 0.154611 & 0.141166 & --- & 0.138839 & 0.186977 & 0.213998 & 0.133726 & 0.248576 & 0.268268 & & 0.657955 \\
\hline 分散(お笑い) & 0.835952 & 0.842319 & ב--- & 0.734098 & 0.972548 & 0.808129 & 0.730324 & 0.801523 & 0.778760 & 0.643596 & \\
\hline
\end{tabular}

